\title{
Political Interest and Participation of Youth in Albania: The Views of the Youth
}

\section{Dr.İsa Erbaş}

Bedër University

ierbas@beder.edu.al

\section{Doi:10.5901/ajis.2014.v3n6p251}

\section{Abstract}

Political participation is an important factor in democracy. For this reason, there are various types of election systems in the usages of many countries. It seems that, election systems do not make voters to cast their votes on the day of election, if those people are not interested in politics. Albania is considered a country that has a type of democratic transition which needs to have political participation and interest of its youth in order to establish a solid and strong democratic tradition in the country. This paper examines the youth's views on political participation and interest in politics in Albania. The results are important and demonstrate that the university students are keen on politics. This is very important for the future of Albanian democracy. The results have been compared with other countries in order to understand the phenomenon of political interest of the target group. Further, the democratic transition and evolving tradition of Albanian politics are encouraging. Therefore, this paper concludes that Albania may have a better future, if the youth involved in politics and political activities more and see youth in the political parties and in the parliament.

Keywords: Politics, Political Participation, Youth, Albania.

\section{Introduction}

Participation in politics in public life is very vital for young people, so to make sure that their concerns are taken into consideration, as well as to make it possible for them to affect the general direction of development in society (Florian Bieber, 2008, p. 220). Every citizen has the right to participate in the conduct of public affairs, to have the right to vote and be elected and to have equal access to use the public service in one's own country (Burchill, 2009, p.97). There is not any bias concerning factors such as age, gender and class, somehow they need to participate in politics (Albert Mabileau, 1989, p. 36). For example, the Women and Politics Institute in America is dedicated to develop the study and discussion of women and politics, and train young women to become political leaders (Burrell, 2004, p. 217)

Political participation is very essential for the university students in order to have a better and bright future for a country. All the members of a society should involve in politics, particularly university students, because developed democracy requires intellectuals in order to deal with the future democracy (Pintor, 2002, p.19). For this reason, there are many countries which want their youth to involve in politics during their university education. Thus, participation in politics is not enough. It is a minority activity. Apart from casting votes, majority of people do not get themselves involve in public life. (Albert Mabileau, 1989, p. 5) "Thus, a lack of political interest, a psychological detachment from any political party, being largely outside local associational life, being young and uneducated, are all factors that tend to deactivate individuals in both localities" (Albert Mabileau, 1989, p. 87).

This paper examines the youth' views on political participation and interest in politics in Albania.

\section{Literature Review}

Albanian parties have been most successful in using their participation in the Government in order to meet the demands of the ethnic community they are representing (Florian Bieber, 2008, p.147).

Besides the parties, the civil society of young people is also very active in Albania, in terms of protecting the rights of young people. Youth organizations like 'MJAFT' or Keshilli Rinor, have played an important role in the growth of youth participation in the country's most pressing issues. On the other hand there has been a lack of connection between civil society and youth political forums.

In this regard it can be said that there are two youth movements in Albania;

1. Youth movement of civil society and NGOs;

2. Youth movement of young people from political parties (Memia, 2008). 
Most popular youth political forums of the political parties are the 'Forumi i te Rinjve te Partise Demokratike(Democratic Party Youth Forum)' and that of the Socialist Party; ' Forumi i të Rinjve të Partisë Demokrate e Reformuar (Democratic Party Youth Forum Reformed)', and finally the 'Forumi Rinor i Lëvizjes Socialiste për Integrim (Socialist Movement for Integration Youth Forum)'. These forums have close relations with political parties. It is difficult to say how much the forums impact on the formulation of policies for young people both within the party and in Parliament (Memia, 2008).

The purpose of this forum is to enable the youth to involve in all levels of social and political life in the country, to promote democratic culture among young people and to help them be active citizens for the future (Aktive, 2011).

There was not much difference in youth voting participation in 2007 and 2009 elections. The results of the elections of 2007 and 2009 provided very interesting results. Only 33\% of young people participated in the local election of 2007, while $67 \%$ of young people did not participate. In the general election of 28 June 2009 the results were almost identical with $35 \%$ of young people participated in the election and $65 \%$ of the young people did not participate. The low participation of the youth in voting resulted from several reasons: first the lack of confidence in political parties and second, the lack of confidence in the proposed candidates (Raport per Rezultate Sondazhi, 201 (Aktive, 2011).

According to this result, it shows that there has not been done not much effort in order to make the young people involve in politics.

\section{Concept of Politics}

Barber states that "Where there is no action, there is no politics" (Barber, 2003, p. 122).For this reason it is very vital for new generation and university students to participate and involve in politics. In general every politics faces the competition of private interests and the conflict that competition engenders. But liberal democracy understands politics as a means of eliminating conflict (Barber, 2003, p. 119).

It has been mentioned above that, politics has a low priority in majority people's lives. This is more important for non-institutionalized forms of participation because in contrast to voting the particular context can provide or not provide opportunities for protesting, signing a petition and making a badge to wear (Goerres, 2009, p. 29).

Politics is invariably corrupted when it becomes generally accepted that the prime function of government is not to insure the rights and liberties of its citizens but to guarantee directly their economic well-being by means of entitlements, transfer payments, quota systems for employment, and the like (G.B.Madison, 1998, p.29) .

From age to age the concerns and understandings are changed about politics. For example, an individual's political experience shapes the way he or she thinks about in politics. Older individuals are more experienced and that is why they can go about politics in a different way from younger people. Older people also try to comply more with social norms (Goerres, 2009, p. 38). Realist thinks that politics is an art of power-to whatever ends it is exercised (Barber, 2003, p. 11). Every politics confronts the competition of private interests and the conflict that competition engenders. But where liberal democracy understands politics as a means of eliminating conflict (Barber, 2003, p. 119).

\section{Democratic Political Participation}

Comparison with the early years there is seen a big increase in participation in politics. This increase is vital for the interpretation of political participation in the old and new democracies. As a result of the globalization of democracy, the heterogeneity of countries and regions that belong to the overall category of democratic countries has increased (Pintor, 2002, p. 14). "In a civil society politics is an immensely great deal more than what professional politicians do" (G.B.Madison, 1998, p.91). Interest in politics is vital for the substance of democracy itself (Martín). Participation alone is not enough in politics but also people need to involve in politics, so they can make and shape the democracy themselves. These aims all contribute to a vision of a better world (Pintor, 2002, p. 19). Democracy is 'rule by the people' not by the whole people but by a majority of people (Berrington, 2003). Since its very early days democracy has been a part of a broader worldwide significance (Müller, pp. 1-14). Democracy changes the notion of majority rule with the idea of individual freedom; especially, democracy seeks to protect its citizens from the wrong use of power by the governors (Berrington, 2003). For this reason, without any discussion all people have to participate in politics.Under strong democracy, politics is given the power of human promise (Barber, 2003, p. 119). "Lastly, if democracy is government by the people, presumably this includes all people, so that it is every citizen's responsibility to elect his or her representatives" (Pintor, 2002, p. 106).

At the beginning of the twenty-first century the future of democracy must be seen in the context of a twofold 
process: first, a process of expansion of democracy in terms of an increase in the number of democracies in the world; and, second, a process of consolidation of democracy in the new democracies. (Müller) The great wave of democratization in the first sense is almost complete. The expansion of democracy will continue, though not as explosively as in the recent past. (Pintor, 2002, p. 18).

\section{The Perception Difference between Old People and Young People in Political Participation}

There is a big difference in old and young people 's perception. We can ask such a question. Why should older people show different patterns of political participation from younger people? We can find two answers to this question: First, older people are different 'from within': they might have different levels of motivation and resources that they can use to involve in politics; second, older people confront different environments from younger people. They might be exposed to a different kind of mobilization to involve in politics or to a different set of advantages for involment. These various social stages create differences in political interests as much as in available resources for involvement in politics. Health, for example becomes worse with age due to the combined effects of the accumulation of unhealthy lifestyles and the physical effects of becoming older. Physical ability can be important for various forms of political participation. This age effect is rooted in the social experience associated with (and often constructed around) a certain age (Goerres, 2009, pp. 12-14).

As people become older the factors of age effect on political behavior, 'individual ageing' affects the likelihood of political participation: these are the accumulated experience and growing adherence to social norms. An older person can fall back, for instance, on many more elections than a younger one and can use that experience to cast his or her vote again. Issues, candidates and the procedure of voting are more familiar to the former than to the latter, entailing lower costs in performing that political action (Goerres, 2009, p. 14).

Goerres states that younger people, who are likely to lose out if political reforms are deferred, and they have a high motivation to vote in order to make their voices heard (Goerres, 2009, p. 47).

It is important to know that whether young people participate less than those of middle age or old people. Because of the age difference, or because young people are less interested in politics than the old people (Albert Mabileau, 1989, p. 61). The young people think that they can find any job anywhere. They do not require much support from others.

There are many factors that change individual's preferences about politics, For example, working people have not much free time to involve in politics than pensioners or parents' interest in children's nurseries. But it can also be determined the amount of motivation and opportunities that an individual has to participate in politics. Older people are in a different social position in the life cycle than younger people, and will accordingly they are different in their political participation patterns (Goerres, 2009, p. 38). Moreover, the most important institutional structures affected by demographic ageing are the welfare state and its programs. More specifically, it matters how many older people are pensioners in a society and how many people are of working age. European welfare states have been constructed on the assumption that a small number of dependant older people would be supported by a large number of people of working age. The rising number of pensioners and decreasing labor market participation rates undermine this. Younger people would therefore have a higher incentive to be active in politics in countries in which the dependency ratio is high in order to have their interests heard. As a result, it is assumed that older generations have on average a lower probability of participating in politics, because they lack necessary resource and motivation to involve in politics (Goerres, 2009, pp. 3637). In many countries older people depend on relatively few working people and public opinion on the subject of older people is very positive, older people are less likely to involve in politics comparison to younger people (Goerres, 2009, p. 2).

\section{Comparison with Other Countries}

There are some countries that youth are not interested in politics. For example in Russia, teenagers and young people are often politically indifferent. There is only 8 percent of youth show any interest in politics. They also show absenteeism: about 70 percent of young people stated that they would not interfere if democracy in Russia appeared to be in jeopardy (Pintor, 2002, p. 54).

The university students in Turkey say that during education periods in university involving in politics is not preferable (Eser).

But in the USA the students who were registered to participate in voting the turnout was high. Nearly $90 \%(88 \%)$ of the students said they were registered to vote. Of these students, nearly $90 \%(88 \%)$ said they voted. There is another 
interesting fact that the rate of turnout is very high when compared to non-college students. For example in 2004 as in other recent years, college students were nearly twice as likely to vote as young people who do not attend college (Hanmer, 2004).

Canada has long embraced the majority electoral politics and remains one of the few major established democracies to cling to the first past the post politics of a single-member plurality (SMP) electoral system (Blais, 2008, $p$. 140). As it has been observed that in many southern African countries youth participation in political processes is declining (Eisa).

\section{Result of the Study}

In order to find out if politics are taught at the secondary schools or not, I have analysed the schools curriculum. I have analyzed the subjects such as: civics, history, philosophy and sociology. I have not found any topics related to politics. The secondary school teachers who teach these subjects state that they do not give any information about politics.

I have also talked with many students about politics. The students, who are about eighteen years old, state that they belong to the society and because of the rights they have to take part in election. After voting they do not want to deal with politics and they also say that they do not have much knowledge about politics.

\section{Discussion of the Result}

It is clearly seen that people discuss and talk about politics every where whereas, they discuss in the cafés, bars, restaurants etc. In addition, public talking increases citizens' store of political capital, which in turn further increases their resources and motivation to act in the political and civic world (Lawrencer . Jacobs, 2009, p. 128).

The research shows that the young generation are not much intersted in politics. They have to be taught at the very early ages. For this reason by giving right information and motivation they have to be directed to the politics. In order to prepare for the future politics, the secondary school students should be acknowleged about politics and they should be aware that the politics is very important for the young generation. The students and adults should be acknowledged about the importance of their voice to be heard in society.

It is very important for the government to have young people involve in politics and listen to their ideas and opinions. To put the matter in a more positive way, the function of politics in both the government sphere and the public sphere more generally should be that of encouraging a free and open deliberative process and a creative discovery procedure whereby the "people's will" is not simply "reflected" or "represented "but is actually constituted (G.B.Madison, 1998, p.88).According to the research and interviews, we have found out that students and adults are not much aware of the importance of involving in politics in Albania. Membership in a civic or community organization has been found to increase the chance that an individual will participate in politics (Amyl.Freedman, 2000, p. 40)

\section{Conclusion}

The past participation experiences affect the future probability of participation. If the youth know that participation in politics brings some kind of gratification and happiness to them that outweigh their costs, they will do it again. If something does not give them enough happiness and gratification, they will hardly do it again.

It is believed that political participation is very important for the young people in order to have a bright and promising future for the country.

For this reason, the parties, the politicians and the government should explain the young people the importance of involvement in politics. Furthermore the young people should be motivated and encouraged in order to involve in politics.

\section{References}

Aktive, F. R. (2011). Raport per Rezultate Sondazhi. Tirane: Forumi Rinia Aktive.

Albert Mabileau, G. M. (1989). Local Politics and Participation in Britain and France. Cambridge: Cambridge University Press.

Amyl.Freedman. (2000). Political Participation and Ethnic Minorities. New York: Routledge.

Barber, B. R. (2003). Strong Democracy Participatory Politics fora New Age. London: University of California Press.

Berrington, H. (2003, May Thursday). Political participation and democracy . Retrieved Dcember Thursday, 2012, from BBC News: http://news.bbc.co.uk/2/hi/programmes/bbc_parliament/2442905.stm

Blais, A. (2008). To Keep or To Change First Past The Post? The Politics of Electoral Reform. Oxford: Oxford University Press. 
Burchill, A. C. (2009). Defining Civil and Political Rights. Farnham: Ashgate.

Burrell, B. (2004). Women and Political Participation. California: A B C CLIO.

Eisa. (n.d.). Retrieved January Thursday, 2013, from Youth participation in political processes in southern Africa: http://www.eisa.org. za/events/yc.htm

Eser, H. B. (n.d.). Üniversite Gençliginin Siyasal Tutumlari Üzerine Bir Inceleme. Retrieved December Friday, 2012, from http://www.yerelsiyaset.com/pdf/kasim2007/17.pdf

Florian Bieber, M. C. (2008). Political Parties and Minority Participation. Skopje : Friedrich Ebert Stiftung.

G.B.Madison. (1998). The Political Economy of Civil Society and Human Rights. London: Routlage.

Globalisation and Democracy: Progress and Paradoxes. Retrieved December Thursday, 2012, from www.trentu.ca/globalpolitics: tp://www.trentu.ca/globalpolitics/documents/Muller075.pdf

Goerres, A. (2009). The Political Participation of Older People in Europe. New York: Palgrave.

Hanmer, R. N. (2004, November). College students in the 2004 Election. Retrieved December Thursday, 2012, from http://generation18.com/pdf/FS_College_Voting.pdf.

Lawrencer . Jacobs, f. a. (2009). Talking Together Public Deliberation and Political Participation in America. London: The University of Chicago Press.

Martín, I. (n.d.). Contending explanations about interest in politics in two new democracies:Greece and Spain. Retrieved December Friday, 2012, from http://www2.Ise.ac.uk/europeanInstitute/research/HellenicObservatory/pdf/2nd_Symposium/Irene_Martin_ paper.pdf

Memia, Y. (2008, September 26). Shqiperia e udhekryqeve Të rinjtë dhe politika.mht. Retrieved January Thursday, 2013, from Shqiperia e udhekryqeve : http://ylbermemia.blogspot.com/2008/09/t-rinjt-dhe-politika.html Müller, K. (n.d.).

Pintor, R. L. (2002). Political Participation in New and Old Democracies. Stockholm: Bulls Tryckeri.

Seetanah, B., Juwaheer, T.D., Lamport, M.J., Rojid, S., Sanneseer, R.V., Sudabar, A.U.,. (2011). Does Infrastructure Matter in Tourism Development. University of Mauritus Research Journal , 17, 89-108. 
